\title{
HUBUNGAN ANTARA DUKUNGAN KELUARGA DAN PERILAKU SELF-MANAGEMENT DENGAN TINGKAT STRES MENJALANI DIET PADA PENDERITA DIABETES MELITUS TIPE 2 DI KELURAHAN NAMBANGAN LOR KECAMATAN MANGUHARJO KOTA MADIUN
}

\author{
Amaliathus Sholikhah ${ }^{1}$ Retno Widiarini ${ }^{2}$ Pipid Ari Wibowo ${ }^{3}$ \\ ${ }^{1}$ Kampus STIKES Bhakti Husada Mulia Madiun, Prodi S1 Kesehatan Masyarakat. Jl. Taman \\ ${ }^{2}$ Praja No. 25, Kecamatan Taman, Kota Madiun, Provinsi Jawa Timur, Indonesia \\ E-mail: amaliatus4@gmail.com
}

\section{THE ASSOCIATED OF FAMILY SUPPORT AND SALF-MANAGEMENT BEHAVIOR AND THE STRESS LEVEL OF DIETING IN TYPE 2 DIABETES MELITUS OF NAMBANGAN LOR SUB-DISTRICT OF MADIUN}

\begin{abstract}
Puskesmas Manguharjo is a health center in Madiun City where the number of diabetes sufferers has increased every year with a total of 2,186 cases in 2019, spread across 4 urban villages, one of which is in the Nambangan Lor sub-district in 2019, there were 109 cases of which their blood sugar was checked. The purpose of this study was to determine the relationship between family support and self-management behavior with the stress level of undergoing a diet in type 2 diabetes mellitus sufferers in Nambangan Lor Village, Manguharjo City, Madiun District. This type of research used a cross sectional study design. The number of samples needed is 86 people with the sampling technique used is simple random sampling using the Chi_Square test. Based on bivariate analysis, variable family support $p=0.021$ and selfmanagement behavior $p=0.006$ proved to be associated with stress levels of dieting in people with type 2 diabetes mellitus in Nambangan Lor Village, Manguharjo District, Madiun City. The results showed that most of the type 2 DM sufferers had poor family support as many as 50 people, had good self-management behavior as many as 46 people and most had moderate stress levels as many as 33 people. Researchers provide suggestions, namely to increase family support for people with diabetes mellitus.
\end{abstract}

Keywords : Diabetes Militus, stress level, family support, diets

\begin{abstract}
Abstrak
Puskesmas Manguharjo merupakan puskesmas di Kota Madiun yang jumlah penderita diabetes mengalami peningkatan setiap tahunnya dengan total keseluruhan tahun 2019 yaitu 2.186 kasus yang tersebar di 4 kelurahan, salah satunya berada di kelurahan Nambangan Lor tahun 2019 terdapat 109 kasus dari yang sudah diperiksa gula darahnya. Tujuan penelitian ini adalah untuk mengetahui hubungan antara dukungan keluarga dan perilaku self-management dengan tingkat stres menjalani diet pada penderita diabetes melitus tipe 2 di Kelurahan Nambangan Lor Kecamatan Manguharjo Kota Madiun. Jenis penelitian menggunakan desain studi cross sectional. Jumlah sampel yang diperlukan adalah 86 orang dengan teknik sampling yang digunakan adalah simple random sampling menggunakan uji Chi_Square. Berdasarkan analisis bivariat, variabel dukungan keluarga $p=0,021$ dan perilaku self-management $p=0,006$ terbukti berhubungan dengan tingkat stres menjalani diet pada penderita diabetes melitus tipe 2 di Kelurahan Nambangan Lor Kecamatan Manguharjo Kota Madiun. Hasil penelitian menunjukkan bahwa sebagian besar penderita DM tipe 2 memiliki dukungan keluarga yang buruk sebanyak 50 orang, memiliki perilaku self-management yang baik sebanyak 46 orang dan
\end{abstract}


sebagian besar memiliki tingkat stres yang sedang sebanyak 33orang. Peneliti memberikan saran yaitu untuk meningkatkan dukungan keluarga kepada penderita diabetes melitus.

Kata kunci: Diabetes militus, tingkat stress, dukungan keluarga, pola makan

\section{PENDAHULUAN}

Diabetes Melitus adalah penyakit metabolisme yang merupakan suatu kumpulan gejala yang timbul pada seseorang karena adanya peningkatan kadar glukosa darah diatas nilai normal. Peningkatan kadar glukosa pada darah diakibatkan karena adanya gangguan pada sekresi insulin, kerja insulin maupun keduanya. Diabetes melitus dapat diklasifikasikan menjadi 4 tipe berdasarkan etiologi penyakitnya yaitu DM tipe 1, DM tipe 2, DM gestasional dan tipe spesifik lainnya. Dari beberapa DM tersebut kejadian penyakit DM yang paling sering terjadi di masyarakat adalah DM tipe 2. DM tipe 2 merupakan klasifikasi penyakit diabetes terbanyak yakni sebesar 90- 95\% dari keseluruhan kejaadian diabetes melitus yang ada. Penyakit DM tipe 2 terjadi akibat adanya resistensi insulin, kerusakan insulin, defisiensi produksi insulin maupun gangguan kerja insulin. DM tipe 2 dikenal dengan noninsulin dependen diabetes melitus (NIDDM) karena mayoritas penderita tidak tergantung pada penambahan insulin.

\section{Menurut World Health Organization} (WHO) tahun 2016, jumlah penderita diabetes mengalami peningkatan dari 108 juta penduduk pada tahun 1980 menjadi 422 juta penduduk pada tahun 2014. Berdasarkan data dari Internasional Diabetes Federation (IDF) pada tahun 2013 Indonesia menempati urutan ke tujuh di dunia dengan jumlah penderita DM yang berumur 20-79 tahun mencapai 8,5 juta jiwa. Sedangkan pada tahun 2017 melaporkan bahwa jumlah pasien DM di dunia mencapai 425 juta orang dewasa berusia antara 20-79 tahun.

Prevalensi penyakit diabetes melitus di provinsi Jawa Timur masuk ke lima besar tertinggi se-Indonesia. Menurut data Riskesdas tahun 2013 angka kejadian penyakit DM sebesar $2,1 \%$ sedangka pada tahun 2018 prevalensi DM menurut diagnosis dokter pada penduduk umur $\geq 15$ tahun mengalami peningkatan yaitu sebesar $2,6 \%$. Dimana angka prevalensi penyakit diabetes melitus tertinggi di provinsi Jawa Timur pada tahun 2018 berada di Kota Madiun dengan angka prevalensi sebesar $4,22 \%$ menurut diagnosis dokter pada penduduk semua umur

Berdasarkan data dari Dinas Kesehatan Kota Madiun jumlah penderita Diabetes Melitus pada tahun 2015 sebanyak 9.202 kasus. Kota Madiun memiliki 6 puskesmas 
salah satunya adalah puskesmas Manguharjo. Puskesmas Manguharjo merupakan salah satu puskesmas di Kota Madiun yang jumlah penderita diabetesnya selalu mengalami peningkatan setiap tahunnya. Pada tahun 2017 jumlah penderita DM sebanyak 1.511 kasus. Sedangkan pada tahun 2018 jumlah penderita DM naik sebanyak 1.919 kasus. Kemudian selama tahun 2019 tercatat jumlah penderita diabetes melitus baru sebanyak 267 kasus.

Puskesmas Manguharjo memiliki 4 kelurahan salah satunya kelurahan Nambangan Lor. Di kelurahan Nambangan Lor pada tahun 2019 penduduk usia 15-59 tahun yang diperikasa gula darah sebanyak 1.548 orang dengan jumlah penduduk lakilaki sebanyak 603 orang dan penduduk perempuan sebanyak 945 orang. Dimana dari hasil pemeriksaan didapatkan ada 33 penduduk laki-laki dan 76 penduduk perempuan memiliki gula darah tinggi (Hiperglikemia $)>200 \mathrm{mg} / \mathrm{dL}$. Sehingga total keseluruhan ada 109 kasus yang terdeteksi memiliki penyakit diabetes melitus. Oleh karena itu, mendorong peneliti untuk melakukan penelitian yang bertujuan untuk mengetahui hubungan antara dukungan keluarga dan perilaku self - management dengan tingkat stres menjalani diet pada penderita diabetes mellitus tipe 2 di
Kelurahan Nambangan Lor Kecamatan Manguharjo Kota Madiun.

\section{BAHAN DAN METODE}

Desain penelitian ini menggunakan pendekatan cross sectional. Populasi dalam penelitian ini merupakan seluruh penderita DM tipe 2 di Kelurahan Nambangan Lor Kecamatan Manguharjo Kota Madiun. Sampel didapat dengan menggunakan teknik simple random sampling dengan kriteria inklusi: 1) Penderita DM tipe 2 yang berusia $\geq 15$ tahun sampai usia $\geq 65$ tahun, 2) Lama menderita DM tipe $2<10$ tahun, 3) Penderita DM yang masih tinggal dengan keluarganya, 4) Penderita DM tipe 2 yang dapat berkomunikasi dengan baik.

Jumlah sampel pada penelitian ini sebanyak 86 responden yang berada di Kelurahan Nambangan Lor Kecamatan Manguharjo Kota Madiun. Data untuk variabel independentnya itu dukungan keluarga dan perilaku self-management, sedangkan untuk data variabel dependen yaitu tingkat stres menjalani diet. Penelitian ini menggunakan instrumen penelitian berupa wawancara dengan penyebaran kuesioner serta hasil penelitian di uji menggunakan uji chi square. 
HASIL

Penelitian ini melibatkan 86 responden sebagai sampel penelitian. Pada Tabel 1 memaparkan karakteristik responden berdasarkan analisis univariat.

Tabel 1. Distribusi Frekuensi Responden Berdasarkan Hasil Analisis Univariat

\begin{tabular}{|c|c|c|c|}
\hline \multirow{2}{*}{ Variabel } & \multirow{2}{*}{ Kategori } & \multicolumn{2}{|c|}{ Frekuensi } \\
\hline & & $\mathbf{n}$ & $\%$ \\
\hline \multirow{2}{*}{ Jenis Kelamin } & Laki-Laki & 35 & 40,7 \\
\hline & Perempuan & 51 & 59,3 \\
\hline \multirow[t]{4}{*}{ Usia } & $36-45$ tahun & 8 & 9,3 \\
\hline & $46-55$ tahun & 21 & 24,4 \\
\hline & $56-65$ tahun & 31 & 36,0 \\
\hline & $\geq 65$ tahun & 26 & 30,2 \\
\hline \multirow[t]{4}{*}{ Pendidikan } & Tamat Pendidikan Dasar & 35 & 40,7 \\
\hline & Tamat Pendidikan & 44 & 51,2 \\
\hline & Menengah & & \\
\hline & Tamat Pendidikan Tinggi & 7 & 8,1 \\
\hline \multirow[t]{7}{*}{ Pekerjaan } & Pegawai & 23 & 26,7 \\
\hline & Wiraswasta & 7 & 8,1 \\
\hline & Ibu Rumah Tangga & 36 & 41,9 \\
\hline & Pedagang & 8 & 9,3 \\
\hline & Sopir & 4 & 4,7 \\
\hline & Buruh & 3 & 3,5 \\
\hline & Pensiunan & 5 & 5,8 \\
\hline \multirow[t]{2}{*}{ Lama Menderita DM } & $1-5$ tahun & 71 & 82,6 \\
\hline & $6-10$ tahun & 15 & 17,4 \\
\hline \multirow[t]{2}{*}{ Dukungan Keluarga } & Dukungan Buruk & 50 & 58,1 \\
\hline & Dukungan Baik & 36 & 41,9 \\
\hline \multirow[t]{2}{*}{ Perilaku Self-Management } & Management Buruk & 40 & 46,5 \\
\hline & Management Baik & 46 & 53,5 \\
\hline \multirow[t]{3}{*}{ Tingkat Stres Menjalani Diet } & Stres Berat & 22 & 25,6 \\
\hline & Stres Sedang & 33 & 38,4 \\
\hline & Stres Ringan & 31 & 36,0 \\
\hline
\end{tabular}


Tabel 2. Hubungan antara Dukungan Keluarga dengan Tingkat Stres Menjalani Diet di Kelurahan Nambangan Lor Kecamatan Manguharjo Kota Madiun

Tingkat Stres Menjalani Diet

\begin{tabular}{|c|c|c|c|c|c|c|c|c|c|c|}
\hline \multirow[t]{2}{*}{ No } & \multirow[t]{2}{*}{$\begin{array}{c}\text { Dukungan } \\
\text { Keluarga }\end{array}$} & \multicolumn{2}{|c|}{$\begin{array}{c}\text { Stres } \\
\text { Berat } \\
\end{array}$} & \multicolumn{2}{|c|}{$\begin{array}{c}\text { Stres } \\
\text { Sedang } \\
\end{array}$} & \multicolumn{2}{|c|}{$\begin{array}{c}\text { Stres } \\
\text { Ringan }\end{array}$} & \multicolumn{2}{|c|}{ Total } & \multirow{2}{*}{$\begin{array}{c}\begin{array}{c}P- \\
\text { value }\end{array} \\
0,021\end{array}$} \\
\hline & & $\mathrm{f}$ & $\%$ & $\mathrm{f}$ & $\%$ & $\mathrm{f}$ & $\%$ & $\mathrm{f}$ & $\%$ & \\
\hline 1 & Buruk & 16 & 32,0 & 26 & 52,0 & 8 & 16,0 & 50 & 100 & \\
\hline 2 & Baik & 6 & 16,7 & 7 & 19,4 & 23 & 63,9 & 36 & 100 & \\
\hline
\end{tabular}

Tabel 3. Hubungan antara Perilaku Self-Management dengan Tingkat Stres Menjalani Diet di Kelurahan Nambangan Lor Kecamatan Manguharjo Kota Madiun Tingkat Stres Menjalani Diet

\begin{tabular}{ccccccccccc} 
No & $\begin{array}{c}\text { Perilaku Self- } \\
\text { Management }\end{array}$ & \multicolumn{2}{c}{$\begin{array}{c}\text { Stres } \\
\text { Berat }\end{array}$} & \multicolumn{2}{c}{$\begin{array}{c}\text { Stres } \\
\text { Sedang }\end{array}$} & \multicolumn{2}{c}{$\begin{array}{c}\text { Stres } \\
\text { Ringan }\end{array}$} & \multicolumn{2}{c}{ Total } & \\
\cline { 2 - 12 } & $\mathrm{f}$ & $\%$ & $\mathrm{f}$ & $\%$ & $\mathrm{f}$ & $\%$ & $\mathrm{f}$ & $\%$ & 0,006 \\
\hline 1 & $\begin{array}{c}\text { Management } \\
\text { Buruk }\end{array}$ & 9 & 22,5 & 21 & 52,5 & 10 & 25,0 & 40 & 100 & \\
\hline 2 & $\begin{array}{c}\text { Management } \\
\text { Baik }\end{array}$ & 13 & 28,3 & 12 & 26,1 & 21 & 45,7 & 46 & 100 & \\
\hline
\end{tabular}

Tabel 1 menjelaskan distribusi karakteristik responden berdasarkan analisis univariat menunjukkan bahwa sebagian besar responden berjenis kelamin perempuan yaitu sebanyak 51 orang $(59,3)$, sebagian besar usia responden $\geq 65$ tahun sebanyak 26 orang $(30,2 \%)$, sebagian besar responden memiliki tingkat pendidikan menengah yaitu sebanyak 44 orang (51,2\%), sebagian besar responden memiliki pekerjaan lain-lain (IRT, pedagang, sopir, buruh dan pensiunan) yaitu sebanyak 56 orang $(65,1 \%)$, sebagian besar responden lama menderita DM kurang lebih selama 1- 5 tahun yaitu sebanyak 71 orang $(82,6 \%)$, sebagian besar responden memiliki dukungan keluarga yang buruk yaitu sebanyak 50 orang $(58,1 \%)$, sebagian besar responden memiliki perilaku self-management baik yaitu sebanyak 46 orang $(53,5 \%)$, dan sebagian besar responden memiliki tingkat stres sedang yaitu sebanyak 33 orang $(38,4 \%)$.

Tabel 2 menunjukkan $\rho=0,021$ yang diartikan bahwa ada hubungan antara dukungan keluarga dengan tingkat stres menjalani diet pada penderita DM tipe 2 di Kelurahan Nambangan Lor Kecamatan Manguharjo Kota Madiun. 
Tabel 3 menunjukkan $\rho=0,006$ yang diartikan bahwa ada hubungan antara perilaku self-management dengan tingkat stres menjalani diet pada penderita DM tipe 2 di Kelurahan Nambangan Lor Kecamatan Manguharjo Kota Madiun.

\section{PEMBAHASAN}

Hubungan antara Dukungan Keluarga dengan Tingkat Stres Menjalani Diet pada Penderita DM tipe 2

Berdasarkan penelitian yang dilakukan pada 86 responden tentang hubungan dukungan keluarga dan perilaku selfmanagement dengan tingkat stres menjalani diet pada penderita DM tipe 2 di Kelurahan Nambangan Lor diperoleh hasil uji bivariat dengan rumus Chi- Square yang menyatakan bahwa ada hubungan antara dukungan keluarga dengan tingkat stres menjalani diet pada penderita DM tipe 2 di Kelurahan Nambangan Lor Kecamatan Manguharjo Kota Madiun dengan nilai $\rho$-value sebesar $(0,021)<\alpha$ $(0,05)$, artinya menyatakan adanya hubungan yang signifikan antar variabel yang diteliti.

Hal ini terjadi karena terkadang penderita DM merasa bahwa kurang mendapat perhatian dari keluarganya sehingga mereka merasa kesulitan dalam mengendalikan penyakit yang dideritanya. Untuk mengatasi kesulitan-kesulitan tersebut mereka memiliki koping yang bagus dalam mengatasi rasa stresnya sehingga hanya memiliki tingkat stres yang sedang. Selain itu responden yang dukungan keluarganya buruk dan memiliki tingkat stres berat yaitu sebanyak 16 orang $(32,0 \%)$. Hal ini karena rata-rata dari mereka tidak mendapat dukungan dari keluarga mengenai pengendalian penyakit DM yang dideritanya, sehingga mereka merasa percuma untuk melakukan pola hidup sehat dan diet karena penyakit DM tipe 2 tidak dapat disembuhkan secara total.

\section{Hubungan antara Perilaku Self- Management dengan Tingkat Stres Menjalani Diet pada Penderita DM tipe 2}

Berdasarkan penelitian yang dilakukan pada 86 responden tentang hubungan dukungan keluarga dan perilaku selfmanagement dengan tingkat stres menjalani diet pada penderita DM tipe 2 di Kelurahan Nambangan Lor diperoleh hasil uji bivariat dengan rumus Chi- Square yang menyatakan bahwa ada hubungan 
antara perilaku self-management dengan tingkat stres menjalani diet pada penderita DM tipe 2 di Kelurahan Nambangan Lor Kecamatan Manguharjo Kota Madiun dengan nilai $\rho$-value sebesar $(0,006)<\alpha$ $(0,05)$, artinya menyatakan adanya hubungan yang signifikan antar variabel yang diteliti.

Sebagian besar responden yang tingkat stresnya sedang dan memiliki perilaku selfmanagement buruk dikarenakan mereka sebenarnya telah mengetahui anjuran diet tetapi tidak mematuhinya karena beranggapan bahwa makanan diet untuk penderita DM tidak menyenangkan sehingga mereka makan sesuai keinginan bila belum menunjukkan gejala yang serius. Selain itu responden yang perilaku self-management baik dan memiliki tingkat stres berat sebanyak 13 orang $(28,3 \%)$. Hal ini disebabkan sebenarnya mereka telah melakukan perawatan diri dengan baik, namun terkadang mereka merasa jenuh dan stres ketika harus mengatur pola makan dengan anjuran diet yang terasa menyusahkan, sehingga sebagian dari responden banyak yang memilih makanan yang tidak sehat.

\section{KESIMPULAN}

Hasil penelitian menunjukkan sebagian besar penderita DM tipe 2 di Kelurahan Nambangan Lor Kecamatan Manguharjo Kota Madiun memiliki dukungan keluarga yang buruk, sebagian besar penderita DM tipe 2 di Kelurahan Nambangan Lor Kecamatan Manguharjo Kota Madiun memiliki perilaku self-management yang baik dan sebagian besar penderita DM tipe 2 di Kelurahan Nambangan Lor Kecamatan Manguharjo Kota Madiun memiliki tingkat stres yang sedang. Kemudian diketahui ada hubungan yang signifikan antara dukungan keluarga dan perilaku self-management dengan tingkat stres menjalani diet pada penderita DM tipe 2 di Kelurahan Nambangan Lor Kecamatan Manguharjo Kota Madiun.

\section{UCAPAN TERIMA KASIH}

Ucapan terima kasih disampaikan peneliti yang telah berkontribusi dalam penelitian ini, sehinngga peleitian ini dapat terlaksana dengan baik.

\section{DAFTAR RUJUKAN}

1. Abbasi, Y. F., et al. (2018). Diabetes Knowledge, Attitude and Practice Among Type 2 Diabetes Melitus Patient in Kuala Muda District Malaysia A cross sectional study Diabetes \& Metabolic Syndrome: Clinical Research \& Review, 1 2 (6), 1057-1063

2. Chin, Y. W., Lai, P.S.M \& Chia, Y.C. (2017). The Validity and Reability of The 
English Version of The Diabetes Distress Scale for Type 2 Diabetes Patients in Malaysia. BMC Family Practice, vol 18 (1) 1-8

3. Deasti, N \& Sugiyanto. (2018). Gambaran Distres pada Penderita Diabetes Melitus. Jurnal Keperawatan, 6 (1), 76-82

4. Derek, M., Rottie, J., \& Kallo, V. (2017). Hubungan Tingkat Stres Dengan Kadar Gula Darah Pada Pasien Diabetes Melitus Tipe Ii Di Rumah Sakit Pancaran Kasih Gmim Manado. Jurnal Keperawatan, 5(1), $1-6$

5. Fatimah. (2016). Hubungan Faktor Personal dan Dukungan Keluarga dengan Manajemen Diri Penderita Diabetes Melitus di Posbindu Wilayah Kerja Puskesmas Pisang Kota Tangerang Selatan. Jurnal Keperawatan http://repository.uinjkt.ac.id

6. Fitriani, A.D. (2018). Hubungan Manajemen Diabetes Dengan Kontrol Gula Darah Pasien Diabetes Melitus Tipe 2. Jurnal Pendidikan Kedokteran Universitas Lampung. http://digilib.unila.ac.id/30054/3

7. Maghfirah, S., Ketut, S \& Ika, Y., W. (2015). Relaksasi Otot Progresif terhadap Stres Psikologis dan Perilaku Perawatan diri Pasien Diabetes Melitus Tipe 2. Jurnal Kesehatan Masyarakat, (2), 137-146

8. Medical Dictionary. (2017). SelfManagement Approach. Diambil tanggal 15 Desember 2019 dari http://medical dictionary. Thefreedictionary.com/selfmanagement

9. Ostrom, E. (2015). Analisis Pengaruh Kepatuhan Pola Diet DM Terhadap Kadar Gula Darah DM Tipe II. Journal of Chemical Information and Modeling, 53(9), 1689-1699

10. PERKENI. (2015). Konsensus Pengelolaan dan Pencegahan Diabetes Melitus Tipe 2 di Indonesia. Jakarta: PB PERKENI

11. Permana, Y. I. (2017). Hubungan antara
Lama Sakit dengan Tingkat Distres pada Pasien dengan Diabetes Melitus di Rumah Sakit Islam Surakarta. Diambil dari http://eprint.ums.ac.id/52058/2/NASKAH \%PUBLIKASI.pdf

12. Pramesti, T. A., Agung, A., Ari, G., \& Firdaus, Z. (2019). Dukungan Keluarga Dan Tingkat Stres Pasien Diabetes Melitus Tipe 2 Stikes Wira Medika PPNI Bali Angka tersebut menunjukkan Indonesia Berdasarkan Rikesdas provinsi Bali untuk melaksanakan berbagai rutinitas melitus, selain membutuhkan perawatan menurunkan stres pada penderita dalam Pittsburgh Epidemiology of Diabetes pengobatan dan dukungan tersebut juga terdapat hubungan antara dukungan keluarga dengan glukosa darah pada pasien diabetes melitus tipe II . Pasien. 3(November)

13. Rosjidi, C.H., Laily, I. \& Nurul, S.W. (2017). Penyusunan Proposal dan Laporan Penelitian Step by Step. Yogyakarta: Unmuh Ponorogo Press

14. Seligman, H.K., Smith, M., et al. (2018). Comprehensive Diabetes SelfManagement Support from Food Banks A Randomized Controlled Trial. American Journal of Publik Health. 108 (9), 12271234 https://doi.org/10.2015/AJPH.2018.30452 8

15. Setyorini, A. (2017). Stres dan Koping pada Pasien Dengan DM Tipe 2 dalam Pelaksanaan Manajemen Diet di Wilayah Puskesmas Banguntapan II Kabupaten Bantul. Health Sciences and Pharmacy Journal, 1(1), https://doi.org/10.32504/hspj.v1i1.3

16. Zainudin, S.B., Abu Bakar, K.N.B., et al. (2018). Diabetes Education and Medication Adjustment in Ramadan (DEAR) Program Prepares for SelfManagement During Fasting With TeleHealth Support from Pre-Ramadan To Post-Ramadan. Therapeutic Advance in Endocrinology and Metabolism. 9 (8), 231-240 